better than his own? And in technical questions such as that of agricultural method, has not the European sometimes had to recognize that this is not so?

Again, the courses in African economics and sociology proposed for the new University College represent a key to the understanding of the world around them that would be a boon to many a student of a European University. But where is the material on which such courses are to be given? Of how many tribes in the area which this college is to serve have we enough knowledge to give even a bare outline of the subjects mentioned?

The Commission's recommendations presuppose a knowledge of the existing circumstances of African peoples which at present is simply not there: and if they are implemented on the basis of assumptions rather than of ascertained facts there is a real danger that the result may prove as inadequate to actual needs as the early systems of education whose insufficiency has now been recognized. (Communicated by DR. L. P. MAIR.)

\title{
History Text-Books for Schools in British Tropical Africa.
}

AN Editorial Board, of which Professor R. Coupland is chairman, has been formed for the study of problems connected with the teaching of history in African schools in areas under British control and for the production of suitable text-books. A leaflet published by the Board says that although the need for: such books is urgent the time has not yet come to plan or write text-books for a completely articulated African school history course, and that at present a large variety of experimental work is required, which should make it possible to determine the lines along which an African history course should proceed.

It will be generally agreed that a fundamental object of instruction in history is to help the pupil to a better understanding of the world in which he lives, by showing him how the present grew out of the past and how the two are interrelated. The world of the African is his own tribe or people, the colony or other political unit in which his people lives, as well as other parts of Africa belonging to the same European Power as his own country, and in a wider sense, the whole continent of Africa, in the political and racial problems of which young Africans take an increasing interest. Since, however, Africa is being reshaped by the white man, African students will also have to understand not only the outward phenomena of European civilization, but also the spiritual forces on which they are based, and this can be learned to a great extent from history.

The first step should be to make the pupil feel at home in his own surroundings and their cultural past. He should not be given the impression that his country and people and what has happened to them in days gone by are not worth serious consideation. Such a preliminary course should start with 'Africa before the White man came'. Practically every tribe or group of tribes has traditions concerning its own past. These should be scientifically 
investigated and collated with those of other units. In most cases this is quite possible; it is surprising to see how faithfully historical traditions have in many cases been kept and how many data of the past can be fixed. But serious investigation is necessary, and as many reliable facts as possible should be ascertained. It is no use talking about the ' great kingdoms of Mali and Ghana ' and to try to link up the history of a tribe with those states, if in reality there is no such connexion. It should further be remembered that, in Africa more than in more advanced countries, civilization is one indivisible unit and history cannot be studied in isolation from the general cultural background of which it is a part. A history book might be envisaged as giving a living picture of the entire life of a people based on the past. It would include geography, economic, social, religious, and political life and would try to show how present conditions developed out of a former stage, through migrations, by peaceful or warlike contacts with neighbours, through the activities of leading personalities, through gradual improvement in working methods and an advance in social and political institutions. If these various factors are welded together into a colourful ' cultural history' in which the people themselves and their ancestors are the actors, it might well help to give students a healthy self-consciousness and a clearer view of the way to a greater and better future. It would also help them to realize that the modern influences coming from abroad do not form a new world out of nothing, but can only fertilize and bring to full fruition their own cultural heritage from the past.

In the leaflet referred to it is said that there are some who hold that in books for Africans history "should be treated mainly on geographical and economic lines, and that it should keep as far as possible from abstract ideas and controversial issues'. Such a limitation will not be acceptable in every case. Important as economic problems are, their weight should not be overstressed in teaching children, for they are apt to foster a materialistic view which may keep students from searching for the deeper sources of life. It may be true that even among older students there are few who take an interest in abstract ideas and controversial issues, but the number of such students will grow. In talking with educated young Africans one will, among many others, also find those who are seriously desirous not only of knowing facts but of understanding the powers which brought them about, who want to look behind the curtain and to see the inner side of European history. They might satisfy their desire by reading books intended for European students, and some will do so, but it is a different thing to give them books written by people who understand the needs and outlook of African pupils and are able to look at history from the African standpoint, for only then will African students be in a position to see European problems in their true light.

The leaflet (which is distributed free of charge by the Oxford University 
Press) solicits the collaboration of educationists working in Africa. Its concluding paragraph is: " The primary purpose of the Board is to get into touch with those who have written, are writing, or want to write books, but they will also be glad to hear from any who, while not themselves prepared to write, have views about the sort of history books they would like to be written. All communications should be addressed to Professor R. Coupland, All Souls College, Oxford.'

\section{South African Institute of Race Relations.}

DURING the seven years of its existence the South African Institute of Race Relations has gradually become the important centre of many forms of activity concerned with a better understanding between races living in South Africa, and notably between Whites and Natives. The report for the year 1936 provides ample proof of this. Of its varied content a few points may be mentioned here as showing how many-sided and far-reaching the activities of the Institute have become and how large a number of other bodies, official and private, are collaborating with it.

I. The Institute gives assistance to the Tiger Kloof Native Institution in studying the possibilities of developing cottage or village industries in native areas. The prospects for such ' home'-industries seem to be limited; they are dependent mainly on the European market, since the Africans have ' a strong prejudice against native-made goods'.

2. The Council of the Institute makes grants for educational and social research; a study of the mental and physical development of the Bantu preschool child from a clinical point of view is now being made, as is also a study of the incidence and origin of miscegenation in South Africa.

3. The problem of harmonizing the efforts to place the uprooted rural White in industrial employment with the claims of Non-European workers to the right to keep the employment they have held for generations, has been studied continuously. In July, 24 natives serving as crews on the tugs in Durban Harbour, were given one day's notice to decide whether they would accept work in the sheds at half their wages or cease work at once. Their periods of service ranged from to to 30 years. Non-European workers are often suspicious of any effort to increase wages because they fear that the underlying motive is their removal from employment.

4. The Institute continues its efforts to find further opportunities for the training of Bantu, Coloured, and Indian nurses. The Institute has been called upon for advice and help in the planning of district nursing services by missionary and other bodies.

5. The increasing interest taken by Bantu women in the welfare of their people has called for the development of Bantu women's societies and the Institute's services have been enlisted by groups of Bantu women to help in the establishment of these societies. 